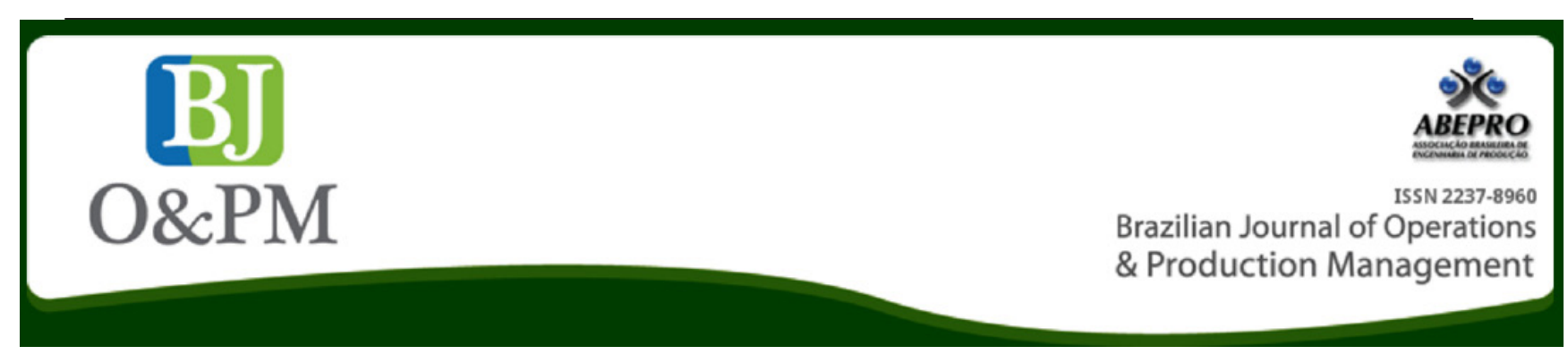

\title{
LEAN E-HEALTH CARE: ITS PERFORMANCE IMPROVEMENT BASED ON BRAZILIAN UNIVERSITY HOSPITAL CASE STUDY
}

\author{
Úrsula Maruyamaa; Leonardo Luiz Braun ${ }^{\mathrm{b}}$; Gustavo Stendera; Paloma Martinez ${ }^{\mathrm{c}}$; Augusto Reis ${ }^{\mathrm{a}}$

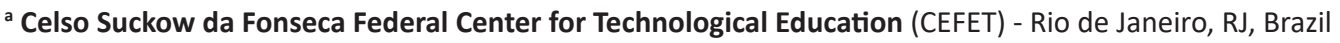 \\ b Julio Muller University Hospital (JMUH) - Cuiabá, MT, Brazil \\ ' University El Bosque (UEBOSQUE) - Bogota, Colombia
}

\begin{abstract}
This paper aims to demonstrate how simple initiatives on public health sector are able to improve quality on service level. One of the most important aspects considered on this case study was the potential and motivation within University Hospital IT team to achieve excellence. Thus, management improvement started from quality management techniques applied by IT members to enhance results. This qualitative study case based on quality program deployed comparative analysis from literature to hospital IT management real initiatives. Results contribution demonstrate that inclusion and the development of collaborative workgroups can make difference to work environment and quality of service.
\end{abstract}

Keywords: Lean manufacturing; hospital university; e-health; IT quality management. 
Brazilian Journal of Operations \& Production Management

Volume 13, Número 4, 2016, pp. 442-450 DOI: 10.14488/BJOPM.2016.v13.n4.a4

\section{INTRODUCTION}

The main right that patients have when they are in a hospital unit is to be treated with dignity and receive all information and medication needed to be treated and recover from illness. On the hospital's perspective, this could be reached in an easier way by improving its quality (Molina-Garduza et Rivera-Barragán, 2012; Razzaque et Karolak, 2010).

Another point to patient satisfaction is due to the waiting time. If it takes more than 15 minutes to medical care, patient satisfaction tends to decrease (Chadha et al., 2012). According to Gholami et al. (2015) IT systems could be used as mean to increase productivity by the standardization of tasks and processes facilitating health care attendance amongst different staff members.

In a hospital, quality environment changes and programs should be developed. They also have to consider safety aspects for staff and patients to maintain the hospital area free of contamination or any risk (Pumar-Méndez et al., 2014). In this way, Chadha et al. (2012) describe the possible transformation when lean healthcare is adopted, providing ways to deliver high quality services at lower costs based on cultural change and quality management tools.

As described by Longarai et Ensslin (2014), public teaching hospitals has to follow some quantitative ratios determined by Unique Health System (known in Brazil as SUS - Sistema Único de Saúde) as number of newly trained doctors per year, bed occupancy rate. On the other hand, some management indexes used to evaluate teaching hospitals performance are not covered by the UHS determination. Therefore, the aim of this paper is to demonstrate the management improvement starting from IT team associated to quality management techniques applied to university hospital staff to transform results.

The following topics of this paper are the theoretical framework addressing the characterization of subjects such as teaching hospital, the usage of lean tools and techniques to improve the hospital management. Then, the methodology is shown followed by the case study results and its conclusions.

\section{TEACHING HOSPITAL CHARACTERISTICS}

In any health system, teaching hospital is included because it has an important role of developing professionals in high complexity cases. It is also the place of development and research of critical diseases and new treatments. So its quality directly affects student learning and the entire health system (Vieira, 2015; Medici, 2001).

Teaching hospital is also an alternative to provide practical cases for students and newly trained doctors. In its structure the main element is the scope brought by patients for services that must support diverse specialization performed in medicine and related areas (Witiuk, 2014).

Like any other kind of hospital, public teaching hospital works by turns to serve a $24 \times 7$ attendance even without having the emergency service (Costa et al., 2000). So, the management of time, costs, performance and service quality is really important. Attendance should be the best provided with limited resources (Pissinati et al., 2014).

In this sense, the importance of introducing management techniques on IT systems to control material resources, information, ensure quality of health care. Thus, it is critical to determine KPIs (key performance indicators) and goals to be accomplished by staff and managers, in coherent internal strategy (Longaray et Ensslin, 2014).

\subsection{Lean as a management technique to hospitals}

In healthcare operations, activities must have the highest added value possible to patient, so all activities that do not represent value to the process must be analyzed and removed (Martínez et al., 2014). Gutsche et al. (2014) describe the relevance of remodeling processes and activities on healthcare operations to improve performance and become more economic.

Activities which value is very low or inexistent are considered waste on lean methodology, and this waste should be allocated on one of the seven types of wastes' described on the Lean method (over production, inventory, transportation, rework, waiting, over processing, movement).

The reason for choosing lean to improve healthcare practices is explained by the similarity of concepts between both methods emphasizing their activities on customer (patient) focus, workforce participation, and continuous improvement to reduce waste (D'Andreamatteo et al., 2015; Burgess and Radnor, 2013).

The applicability of lean on healthcare operations is proven by the increasing number of studies over this topic in the last decade (White et al., 2014; Skeldon et al., 2014; Martin et al., 2014; Martinez et al., 2015; D'Andreamatteo et al., 2015; Vermuelen et al., 2014).

This expansion in lean healthcare on hospitals and medical clinics have been largely due to the need to serve a great number of people with a restricted budget and the need to offer a high level of quality service (Reznick et al., 2014; Holden et al., 2015; Warner et al., 2013; Chadha et al., 2012).

Furthermore, it is possible to develop plans to enhance safety, effectiveness and reliability of process focused on patients' needs and hospital goals (Simon et Canacari, 2014). Aguilar-Escobar and Garrido-Vega (2013) as well as Aguilar- 
Escobar et al. (2013) cite the majority of academic scholars on lean healthcare focuses on topics as implementation barriers, the usage of IT systems, process redesign, and activities integration.

In this context, Ker et al. (2014) mention management tools, IT systems and other techniques contribution to allow healthcare units to accomplish their goals. For instance, it is used with lean methodology, time studies, and cost analysis. All can support the improvement strategy to enhance accuracy and efficiency, consequently improving the perceived quality by patients (Chadha et al., 2012).

\subsection{Improving efficiency by management tools}

The present moment for hospitals and health clinics is extremely critical because of the rising costs and growing demand. On this perspective, hospitals must look internally to evaluate and select performance tools to improve control methods and efficiency (Langabeer II et Helton, 2015).

Pumar-Méndez et al. (2014) believe that quantitative methods and self-administered questionnaires are widely used in healthcare area because their results are easily computed and transformed into data and information about sectors. But the authors advise that these tools cannot go deeper into questions due to the inarticulate characteristic of these methods.

An alternative to go further on the analysis understanding is using qualitative methods, allowing participants to express their beliefs, values and norms (Pumar-Méndez et al., 2014). The adoption of IT systems associated to management tools contribute to change hospital activities into modern and well managed perspective (Cintra et al., 2012).

The integration of different techniques allows hospital to develop business management based on metrics and goals as it uses financial resources, materials and information (Sguario et Silva, 2010). Based on successful cases available on the read literature, (chart 1) it is deployed the most used tools.

The aforementioned framework depicts what lean healthcare tools can contribute to wider its application in hospitals and academic studies. Finally, this case study will implement choice over quality management tools.

Chart 1 - Framework of main lean tools used on healthcare cases

\begin{tabular}{|c|c|c|}
\hline Tool & Definition & Authors \\
\hline $\begin{array}{l}\text { Value } \\
\text { Stream } \\
\text { Mapping } \\
\text { (VSM) }\end{array}$ & $\begin{array}{l}\text { This tool could be used to map the stream value of a product or service, } \\
\text { taking into consideration all activities with added value or not on customer's } \\
\text { perspective. And stressing points like information flow, materials flow, values } \\
\text { and performance indicators. The main point of this tool is to localize and show } \\
\text { the activities that could be considered waste on the process and mitigate them, } \\
\text { redesigning the process to be leaner and support the demand. }\end{array}$ & $\begin{array}{l}\text { Burgess et Radnor (2013); Mcintosh et al. (2014); } \\
\text { Hussain et al. (2015); Da Silva et al. (2015); } \\
\text { Drotz et Poksinska (2014); Al-Balushi et al.(2014); Miller } \\
\text { et Chalapati (2015); Guimarães and Carvalho (2013); } \\
\text { Reznick et al. (2014); } \\
\text { Martin et al. (2014); Kates (2014); Zhu et al. (2014); } \\
\text { Martínez et al (2014); Martínez et al (2015); Digioia et al. } \\
\text { (2015); Touissant et Berry (2013). }\end{array}$ \\
\hline $5 S$ & $\begin{array}{l}\text { This tool allows the workers to organize their work areas and develop the } \\
\text { organizational culture on environmental aspects, equipment basic maintenance, } \\
\text { organize materials flow, emphasize the method, metrics and people. The } \\
5 S \text { program is based on five senses focused on sustain the cleanness of the } \\
\text { environment, maintaining only the necessary things, support to initiatives } \\
\text { that contribute to better health to their works, and the auto discipline that is } \\
\text { extremely important and necessary to sustain the program working. }\end{array}$ & $\begin{array}{l}\text { Burgess et Radnor (2013); Drotz et Poksinska (2014); } \\
\text { Laureani et al. (2013); Guimarães et Carvalho (2013); } \\
\text { Martin et al. (2014); } \\
\text { Kates (2014); Dávila et González (2015); } \\
\text { Knechtges et al. (2013); Touissant et Berry (2013). }\end{array}$ \\
\hline Kaizen & $\begin{array}{l}\text { Also known as the continuous improvement program is based on commitment. } \\
\text { This management tool pursuit for manners to increase productivity and financial } \\
\text { return to the activity since it has the minimum impact possible on costs. }\end{array}$ & $\begin{array}{l}\text { Burgess et Radnor (2013); Da Silva et al. (2015); } \\
\text { Drotz et Poksinska (2014); Timmons et al. (2014); Simon } \\
\text { et Canacari (2014); Kates (2014); } \\
\text { Zhu et al. (2014). }\end{array}$ \\
\hline $\begin{array}{l}\text { Lean Six } \\
\text { Sigma }\end{array}$ & $\begin{array}{l}\text { Toolbox of statistics methods aiming to improve process in a systematic way to } \\
\text { reduce defects. The main goal is to obtain planned results in a known scenario } \\
\text { allowing financial income. }\end{array}$ & $\begin{array}{l}\text { Abdallah (2014); Timmons et al. (2014); Laureani et al. } \\
\text { (2013); Gijo et al. (2013); Reznick et al. (2014); Warner et } \\
\text { al. (2014); Lighter (2014). }\end{array}$ \\
\hline Muda & $\begin{array}{l}\text { Categorization of activities in a product or service where the customer did not } \\
\text { see added value by the types } 1 \text { and } 2 \text {, which correspond respectively to the } \\
\text { activities that cannot be removed immediately from the process and the other } \\
\text { that can be removed. }\end{array}$ & $\begin{array}{l}\text { Chaudhuri et Lillrank (2013); Al-Balushi et al. (2014); } \\
\text { Timmons et al. (2014); Guimarães and Carvalho (2013); } \\
\text { Martin et al. (2014); Mason et al. (2015). }\end{array}$ \\
\hline Kanban & $\begin{array}{l}\text { Signalization tool to control production flows in a visual way by using a color } \\
\text { card for each kind of activity, to turn the routine of activities more agile where } \\
\text { implemented since the material picking to the financial flow. }\end{array}$ & $\begin{array}{l}\text { Aguilar-Escobar et Garrido-Vega (2013); Dávila et } \\
\text { González (2015); Kates (2014); Touissant and Berry } \\
\text { (2013). }\end{array}$ \\
\hline $\begin{array}{l}\text { Takt } \\
\text { Time }\end{array}$ & $\begin{array}{l}\text { Necessary production rhythm to support the demand, being variable according } \\
\text { to the daily demand. }\end{array}$ & Abdelhadi (2015); Abdelhadi et Shakoor (2014). \\
\hline $\begin{array}{l}\text { Poka- } \\
\text { Yoke }\end{array}$ & $\begin{array}{l}\text { Gadget to prevent errors avoiding the chance of interruptions on production } \\
\text { process and the prevention of occupational accidents. This technique aims to } \\
\text { reduce the human error on production flow in specific activities or machines. }\end{array}$ & $\begin{array}{l}\text { Drotz and Poksinska (2014); Aguilar-Escobar et Garrido- } \\
\text { Vega (2013) }\end{array}$ \\
\hline Gemba & $\begin{array}{l}\text { Cultural change of senior management staff to be, at least once a week, walking } \\
\text { on the production line to see and identify improvement opportunities by } \\
\text { observation or interviews with the operational staff. }\end{array}$ & Gijo et al. (2013). \\
\hline
\end{tabular}




\section{METHODOLOGY}

The case study method has been chosen by its usage in social science, psychology, anthropology and ecology. This method is especially useful for trying to test theoretical models by using them in real world situations (YIN, 2014).

Basically, a case study is an in depth study of a particular situation rather than a sweeping statistical survey. It is a method used to narrow down a very broad field of research into one easily researchable topic.

Although it will not answer a question completely, it will give some indications and allow further elaboration and hypothesis creation on a subject. Thus, as qualitative research, it presented a desired approach for our object of study, once Information, Communication and Technology (ICT) will be the core of University Hospital study.

\section{CASE STUDY: JULIO MULLER UNIVERSITY HOSPITAL (JMUH)}

Mato Grosso is one out of 27 Brazil federal units, located in Midwest region. Its north area belongs to the well-known Legal Amazônia. Total area 903.357 km²; its capital is Cuiabá. Population MT: 3,224 million (in July,2014) and Cuiabá population: 542.861 inhabitants (2010). The population earnings per capita is $R \$ 1.032,00$ (US\$295 ${ }^{1}$ ) monthly.

By assuming as Federal University of Mato Grosso dean, in February 1982, Benedito Pedro Dorileo created on March 4, 1982, a group task, coordinated by Professor Eduardo de Lamonica Freire, head of the Department of Medicine (now Faculty of Medical Sciences), to diagnose problems and provide solutions to improve the quality of traineeships in the health area. The task group presented the proposal to raise Júlio Müller University Hospital, by the time renovation and expansion under formal protection assignment use, to turn it into University Hospital.

1 Considering US\$1 = R\$3,50
The Governor signed the Decree No. 2045 of September $14^{\text {th }}, 1982$ and under this act, on December $28^{\text {th }}, 1982$, the university-hospital use was settled for a period of 20 years. Since then, Júlio Müller University Hospital was rebuilt and expanded by the State Government, through the financing of the former Superintendency of Midwest Development (SUDECO).

Since 1992, with National Medical Residency Commission approval, JMUH serves as a fundamental support for medical residency programs in Internal Medicine, General Surgery, Obstetrics and Gynecology, Anesthesiology and Pediatrics, all accredited to date, no restrictions. In 2001 it implanted the Medical Residency Program in Infectious Diseases, endorsed by the CNRM. Now, it is one of the most respect public hospitals in the area.

It is important to acknowledge how institutional framework may impact processes and daily activities. In the following figure, JMUH structure is show.

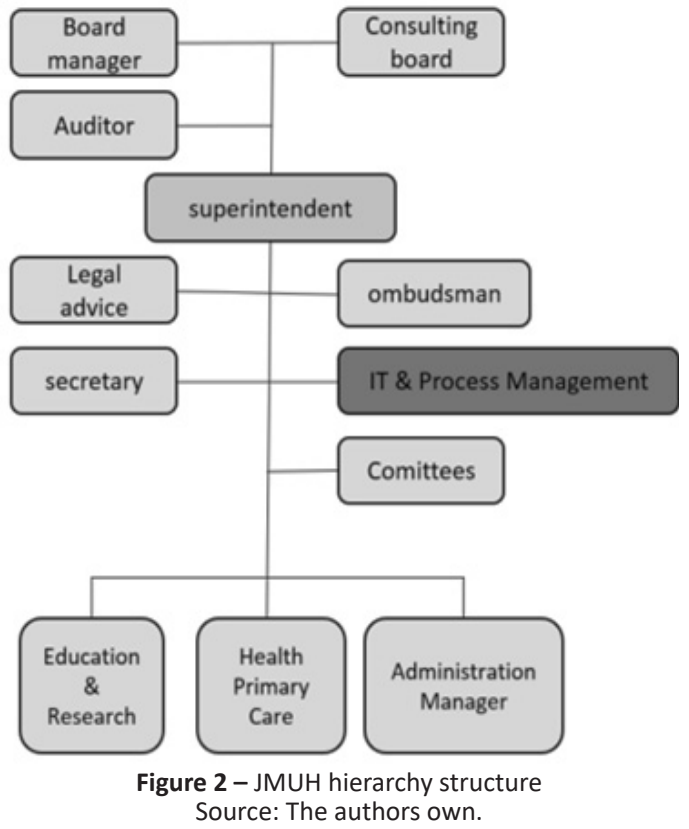

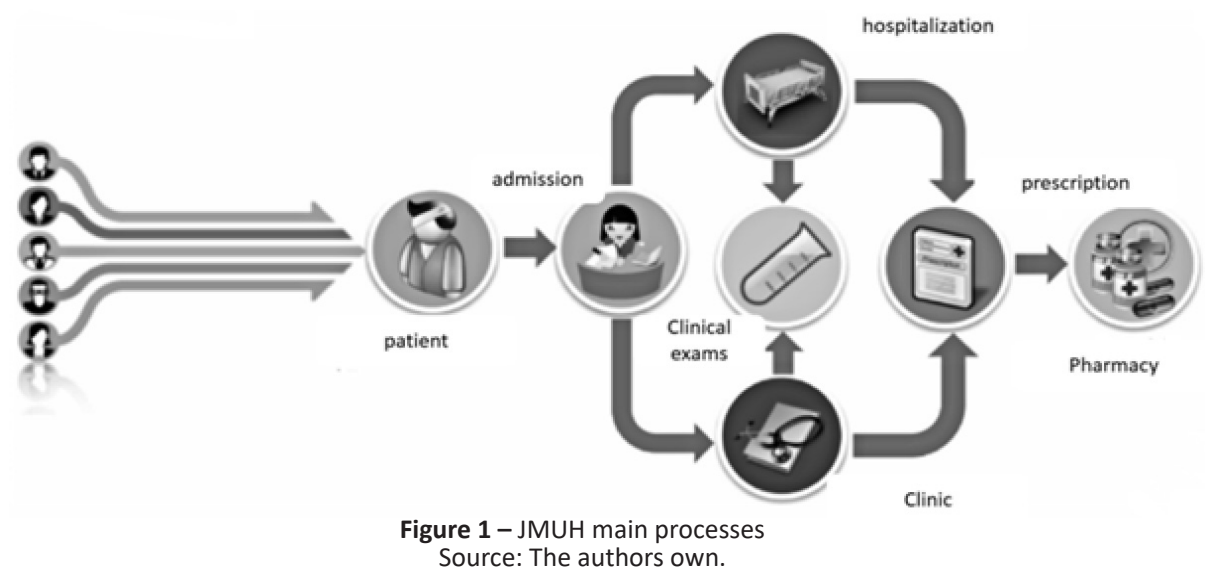

Source: The authors own. 
Since the current IT manager took over (2014), he performs and executes change planning, starting with the motivation of its staff to perform work, volunteers. His expectations were aligned with hospital key drivers:

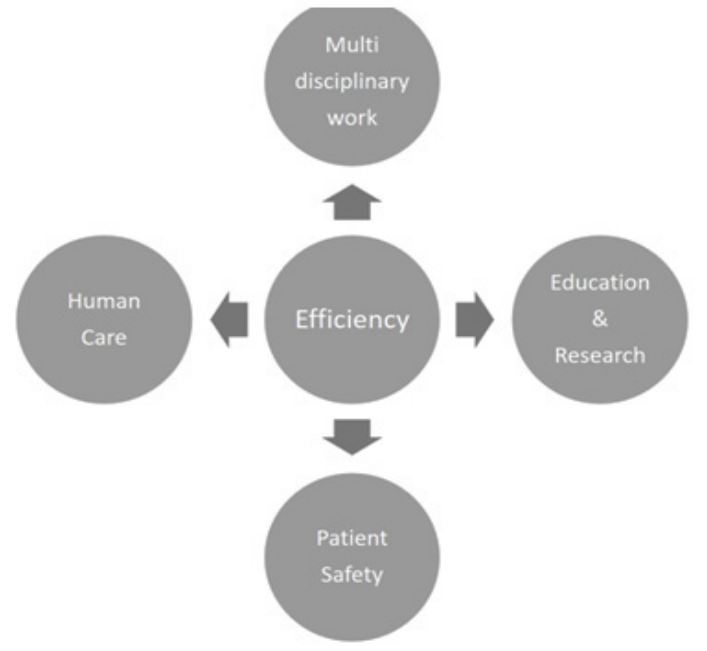

Figure 3 - JMUH Strategic Planning key drivers Source: The authors own.

The "Six Thinking Hats" is useful tool for analyzing decision making, taking into account different points of view (DE BONO, 1999). This technique was cosen by IT manager in order to help distancing from usual thinking styles to a more comprehensive view of a given situation, focusing and analyzing six ways of thinking about a particular subject.

The technique is based on the metaphor that there are six hats of thinking and according to each situation, we must use the most appropriate hat. Each hat has a different color and represents a different style of thinking. So when we think based on a certain hat thinking, we must also change our usual way of thinking.

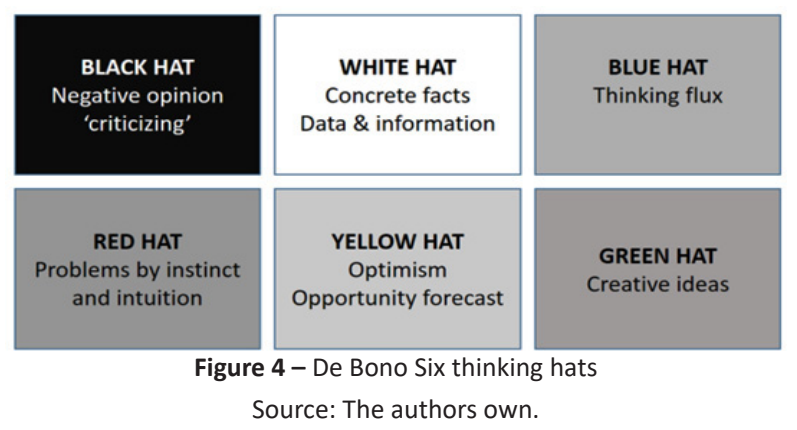

De Bono's Six Thinking Hat technique can be implemented by a group of people looking for a solution to a problem or seeking to find innovative ideas. In this way, JMUH IT team organized their own adapted framework.

The aforementioned theories supported the initiatives taken by this young IT manager and his team during the period from September 2014 to November 2014 and it remains up to now as 'lessons learned'.

\section{RESULTS}

IT manager motivation and team work, made some professionals went beyond regular hours 'pro bono' (without payment), willing to change the work environment and hospital infrastructure, which undergoes structural works (construction).

Their approach was also based on hackathon (also known as a hack day, hackfest or codefest), an event in which computer programmers and others involved in software and hardware development, including graphic designers, interface designers and project managers, collaborate intensively on software projects. In this case, JMUH IT team adapted to infrastructure and hardware component as well.

Chart 2 - JMUH Quality Management tools used during hackathon

\begin{tabular}{|l|l|l|}
\hline \multicolumn{1}{|c|}{$\begin{array}{c}\text { Quality } \\
\text { Approach }\end{array}$} & \multicolumn{1}{|c|}{ Hospital Activity } & \multicolumn{1}{c|}{ Place } \\
\hline $\mathbf{5 S}$ & $\begin{array}{l}\text { Cleaning, organizing, } \\
\text { transforming the viewpoint } \\
\text { and standardization. All team } \\
\text { members were engaged and } \\
\text { compromised with 5S. }\end{array}$ & $\begin{array}{l}\text { IT room, hospital } \\
\text { facilities }\end{array}$ \\
\hline Poka Yoke & $\begin{array}{l}\text { Developing methods to avoid } \\
\text { errors or mistakes. Designing a } \\
\text { tool to identify and prevent IT } \\
\text { migration problems [from older } \\
\text { MV 2000 to AGHU system]. } \\
\text { JMUH ombudsman reported } \\
\text { patient complaint decrease. }\end{array}$ & $\begin{array}{l}\text { Ambulatories and } \\
\text { Medical Laboratory }\end{array}$ \\
\hline $\begin{array}{l}\text { VSM (value } \\
\text { stream } \\
\text { mapping) }\end{array}$ & $\begin{array}{l}\text { Using Six thinking hat approach } \\
\text { from hospital strategy to its } \\
\text { operation. }\end{array}$ & $\begin{array}{l}\text { Julio Muller University } \\
\text { Hospital strategic map }\end{array}$ \\
\hline Kaizen & $\begin{array}{l}\text { Intranet website development to } \\
\text { solve communication problems } \\
\text { amongst administrative and } \\
\text { health areas }\end{array}$ & $\begin{array}{l}\text { Julio Muller } \\
\text { University Hospital } \\
\text { Administrative sectors } \\
\text { and Health care }\end{array}$ \\
\hline $\begin{array}{l}\text { Establishment of a continuous } \\
\text { improvement program. } \\
\text { Partnership with other Health IT } \\
\text { professionals. }\end{array}$ & $\begin{array}{l}\text { Federal University of } \\
\text { São Paulo, Brazilian } \\
\text { Open University and } \\
\text { Julio Muller University } \\
\text { Hospital }\end{array}$ \\
\hline Gembar
\end{tabular}

Source: The authors own.

During a month IT team were engaged in transform its university hospital performance and infrastructure by using from $5 \mathrm{~S}$ approach to kaizen during their hackathon.
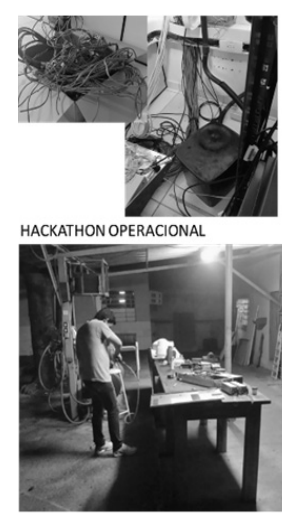
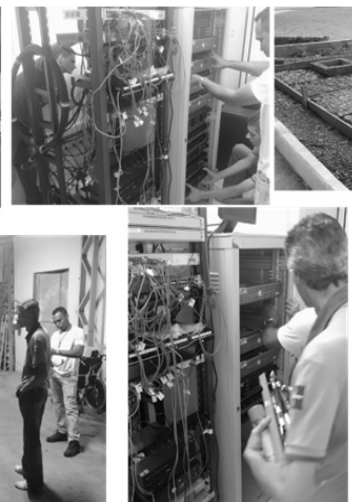

Figure 5 - JMUH operational IT hackathon I Source: The authors own. 
From cockroach nest to nest made with telephone wire, IT team started a hospital facility revolution by cleaning and organizing rooms and data center.

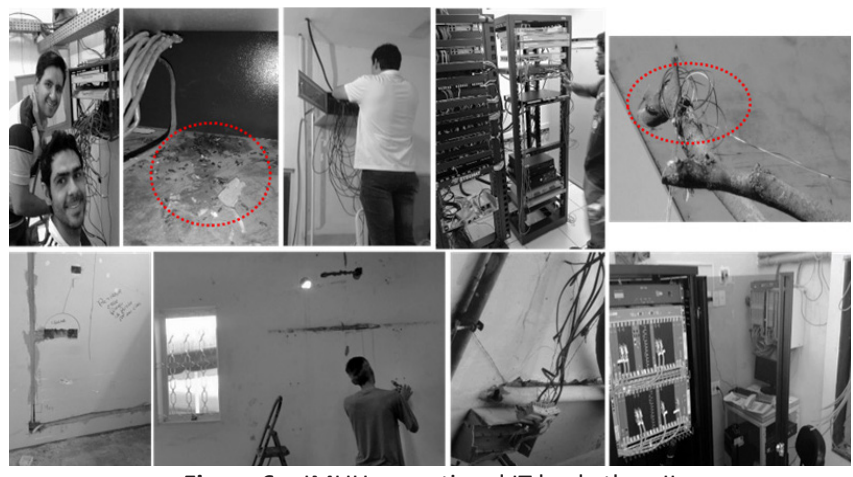

Figure 6 - JMUH operational IT hackathon II Source: The authors own.

One interest data, worth mentioning is RNP network national report. RNP (National Network for Research and Education) is a social organization linked to the Brazilian Ministry of Science Technology and Innovation, responsible for the backbone of the Brazilian academic network. It was established in 1989 and is known to have opened the first backbone for the arrival of the Internet in Brazil in 1991.

Nowadays, RNP provides the public research institutions and tertiary education and technological advanced network infrastructure that enables and facilitates collaborative research in several areas of knowledge. Through these network applications, RNP allows the realization of projects and the implementation of public policies in the areas of technology, education, health and culture.

Since 2002, is a Social Organization (OS) under the Ministry of Science, Technology and Innovation (MCTI) and maintained for this in conjunction with the Ministries of Education (MEC), Culture (Ministry of Culture) and Health $(\mathrm{MoH})$, participating in the Inter-ministerial program RNP (PI-RNP).

In this sense, RNP provides support to its network by monitoring its performance. One RNP key performance indicator (KPI) is the IT network problem, which JMUH used to be in the first place (which means the worst managed net).

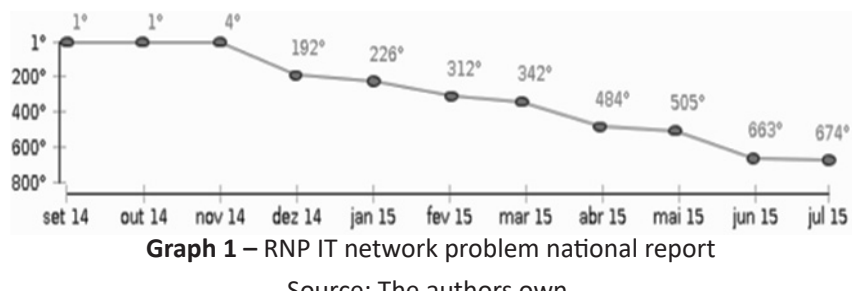

Source: The authors own.

After hackathon and several IT team initiatives, from October 2014 to November 2014 was realized a subtle change from first to fourth place.
Henceforth, the following months revealed an outstanding moving towards excellence: December (192 ${ }^{\text {nd }}$ place); January $\left(226^{\text {th }}\right.$ place); February (312 ${ }^{\text {nd }}$ place); March (342 nd $\left.p l a c e\right) ;$

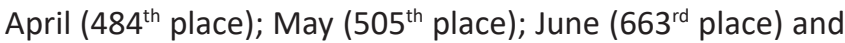
finally in July (674 ${ }^{\text {th }}$ place). From first (worst network) to 674 positions seems to be quite a rewarding effort made for all IT team.

Besides, regarding ICT Service Management, IT team also reported that they consider:

- Stakeholders: in order to contact stakeholders they interview, use survey requirements, meeting with monitoring systems;

- Scope: cited the name of some outstanding professionals in (i) development and maintenance, (ii) networks and (iii) telephony;

- Time (Schedule): Activity Log (using Jira system software internally paid with group crowdsourcing);

- Costs: still early to compliance; some points are centralized by hospital management in Brasilia;

- Risks: they will be report in document by Confluence system (the wiki);

- Communication: using formal and informal means to maintain effective communication between stakeholders;

- Human Resources: it is intended to built competence and collaborative work; shared management; empowerment;

- Acquisitions: it is managed by hospital administration;

- Quality: In JMUH still lacking generally a maturing in the Quality Management (documentary, nonconformity analysis etc.), but IT group effort seems to be changing hospital employees viewpoint;

- Integration: Follow the Jira system which manages several softwares integration.

As 'best practice' IT team settled "the focused day". During daily tasks many technicians realized they were interrupted by nurses, physicians, administrative staff and other hospital employees to solve small problems (or the so called 'IT firefighters support'), but this small breaks caused major delays in important projects. So they decidedthat one professional could have a "focused day", while others would work and help in unpredictable small daily issues. They also used a mind map to deploy each technician activity.

Last, but not least, as a final result, University Hospital dean, invited the IT manager to join JMUH strategic team in a special HR (human resource) and leadership development program organized by Sirio Libanês Hospital in São Paulo 
D Brazilian Journal of Operations \& Production Management Volume 13, Número 4, 2016, pp. 442-450

DOI: 10.14488/BJOPM.2016.v13.n4.a4 state, accountable of preparing strategic goals for the following two years (2016-2017).

Still hard to predict the intangible capital results provided by JMUH IT team members, but it is not hard to forecast if this scenario is maintained, innovation will flourish in university hospital IT programs as well in search of excellence.

\section{CONCLUSION}

This paper intended to deploy how important theories studied throughout Quality Management can be observed in real world. JMUH (a public university hospital) was chosen to provide a broader perception of Production Management working range.

It is important to note how critical is to work in health institutions, especially those connected also with this health professional formation. Furthermore, one key player arises to help Health care: ICTs (information and communication technologies) devices.

Once dealing with life and health care is a challenge, when there is a third component such as technology deploys careful attention and much money invested. More than money, it is critical to have appropriate IT body of technicians well prepared to face any situation.

The case study presented showed that in a short period, a small but well intentioned group of outstanding professionals worked on voluntary hackathon in the hospital, using several Quality management tools and hard work to change health and administrative people viewpoint of information technology.

Money invested was important, but their vision and effective action were more productive in transforming their worst realities into a positive benchmarking to other IT managers. The limitation of this study rely on the short time to cover all topics developed by this group and do not intend to generalize to all kinds of hospital IT services.

Finally, our main contribution to academia, health or IT workers is the report of pure, genuine initiatives, which can make difference when someone believe and make it possible through their own efforts.

\section{ACKNOWLEDGMENT}

Professor Dr. Francisco José Dutra Souto, head of University Hospital Julio Muller.

\section{REFERENCES}

Abdallah, A. (2014) Implementing quality initiatives in healthcare organizations: drivers and challenges. International journal of health care quality assurance, Vol. 27, No. 3, pp. 166-181.
Abdelhadi, A. (2015) Investigating emergency room service quality using lean manufacturing. International journal of health care quality assurance, Vol. 28 , No. 5, pp. 510-519.

Abdelhadi, A., and Shakoor, M. (2014) Studying the efficiency of inpatient and outpatient pharmacies using lean manufacturing. Leadership in Health Services, Vol. 27, No. 3, pp. 255-267.

Aguilar-Escobar, V. G., and Garrido-Vega, P. (2013) Gestión Lean en logística de hospitales: estudio de un caso. Revista de Calidad Asistencial, Vol. 28, No. 1, pp. 42-49.

Aguilar-Escobar, V. G., Garrido-Vega, P., and GodinoGallego, N. (2013) Mejorando la cadena de suministro en un hospital mediante la gestión Lean. Revista de Calidad Asistencial, Vol. 28, No. 6, pp. 337-344.

Al-Balushi, S., Sohal, A. S., Singh, P. J., Al Hajri, A., Al Farsi, Y. M., and Al Abri, R. (2014) Readiness factors for lean implementation in healthcare settings-a literature review. Journal of health organization and management, Vol. 28, No. 2, pp. 135-153.

Burgess, N., and Radnor, Z. (2013) Evaluating Lean in healthcare. International journal of health care quality assurance, Vol. 26, No. 3, pp. 220-235.

Chadha, R., Singh, A., and Kalra, J. (2012) Lean and queuing integration for the transformation of health care processes: A lean health care model. Clinical governance: a international journal, Vol. 17, No. 3, pp. 191-199.

Chaudhuri, A., and Lillrank, P. (2013) Mass personalization in healthcare: insights and future research directions. Journal of Advances in Management Research, Vol. 10, No. 2, pp. 176-191.

Cintra, R. F., Vieira, S. F. A., Junior, D. C. B., Fernandes, C. R., and Baggio, D. K. (2012) Impacto da implantação de um sistema de informação gerencial na gestão de contratos públicos: o caso do hospital universitário de Dourados/MS. Revista de Administração da Unimep - Unimep Business Journal, Vol. 10, No. 2, pp. 28-53.

Costa, E. D. S., Morita, I., and Martinez, M. A. (2000) Percepção dos efeitos do trabalho em turnos sobre a saúde e a vida social em funcionários da enfermagem em um hospital universitário do Estado de São Paulo. Cadernos de Saúde Pública, Vol. 16, No. 2, pp. 553-555.

da Silva, I. B., Seraphim, E. C., Agostinho, O. L., Lima Junior, O. F., and Batalha, G. F. (2015) Lean office in health organization in the Brazilian Army. International Journal of Lean Six Sigma, Vol. 6, No. 1, pp. 2-16.

Dávila, S. P., and González, J. T. (2015) Mejora de la eficiencia de un servicio de rehabilitación mediante 
metodología Lean Healthcare. Revista de Calidad Asistencial, Vol. 30, No. 4, pp. 162-165.

De Bono, E. (1999) Six thinking hats. MICA Management Resources Inc.

DiGioia, A. M., Greenhouse, P. K., Chermak, T., and Hayden, M. A. (2015, December) A case for integrating the Patient and Family Centered Care Methodology and Practice in Lean healthcare organizations. In: Healthcare (Vol. 3, No. 4, pp. 225-230). Elsevier.

Drotz, E., and Poksinska, B. (2014) Lean in healthcare from employees' perspectives. Journal of health organization and management, Vol. 28, No. 2, pp. 177-195.

D’Andreamatteo, A., Ianni, L., Lega, F., and Sargiacomo, M. (2015) Lean in healthcare: A comprehensive review. Health Policy, Vol. 119, No. 9, pp. 1197-1209.

Gholami, R., Higón, D. A., and Emrouznejad, A. (2015) Hospital performance: Efficiency or quality? Can we have both with IT?. Expert Systems with Applications, Vol. 42, No. 12 , pp. $5390-5400$.

Gijo, E. V., Antony, J., Hernandez, J., and Scaria, J. (2013) Reducing patient waiting time in a pathology department using the Six Sigma methodology. Leadership in Health Services, Vol. 26, No. 4, pp. 253-267.

Guimarães, C. M., and Carvalho, J. C. de (2013) Strategic outsourcing: a lean tool of healthcare supply chain management. Strategic Outsourcing: An International Journal, Vol. 6, No. 2, pp. 138-166.

Gutsche, J. T., Erickson, L., Ghadimi, K., Augoustides, J. G., Dimartino, J., Szeto, W. Y., and Ochroch, E. A. (2014) Advancing extubation time for cardiac surgery patients using lean work design. Journal of cardiothoracic and vascular anesthesia, Vol. 28, No. 6, pp. 1490-1496.

Holden, R. J., Eriksson, A., Andreasson, J., Williamsson, A., and Dellve, L. (2015) Healthcare workers' perceptions of lean: A context-sensitive, mixed methods study in three Swedish hospitals. Applied ergonomics, Vol. 47, No. 1, pp. 181-192.

Hussain, A., Stewart, L. M., Rivers, P. A., and Munchus, G. (2015) Managerial process improvement: a lean approach to eliminating medication delivery. International journal of health care quality assurance, Vol. 28, No. 1, pp. 55-63.

Langabeer II, J. R., and Helton, J. (2015) Health care operations management. Burlington: Jones \& Bartlett Publishers.

Laureani, A., Brady, M., and Antony, J. (2013) Applications of lean six sigma in an Irish hospital. Leadership in Health Services, Vol. 26, No. 4, pp. 322-337.
Longaray, A. A., and Ensslin, L. (2014) The usage of MCDA in identification and measurement of criteria performance for certification of public teaching hospitals in Brazil. Production, Vol. 24, No. 1, pp. 41-56.

Kates, S. L. (2014) Lean business model and implementation of a geriatric fracture center. Clinics in geriatric medicine, Vol. 30, No. 2, pp. 191-205.

Ker, J. I., Wang, Y., Hajli, M. N., Song, J., and Ker, C. W. (2014). Deploying lean in healthcare: Evaluating information technology effectiveness in US hospital pharmacies. International Journal of Information Management, Vol. 34, No. 4, pp. 556-560.

Knechtges, P., Bell, C. J., and Nagy, P. (2013) Utilizing the 5S Methodology for radiology workstation design: applying lean process improvement methods. Journal of the American College of Radiology, Vol. 10, No. 8, pp. 633-634.

Lighter, D. E. (2014) The application of Lean Six Sigma to provide high-quality, reliable pediatric care. International Journal of Pediatrics and Adolescent Medicine, Vol. 1, No. 1, pp. 8-10.

Martin, L. D., Rampersad, S. E., Low, D. K., and Reed, M. A. (2014) Mejoramiento de los procesos en el quirófano mediante la aplicación de la metodología Lean de Toyota. Revista Colombiana de Anestesiología, Vol. 42, No. 3, pp. 220-228.

Martínez, P., Martínez, J., Nuño, P., and Cavazos, J. (2015). Mejora en el Tiempo de Atención al Paciente en una Unidad de Urgencias Mediante la Aplicación de Manufactura Esbelta. Información tecnológica, 26(6), 187-198.

Martínez, P., Martínez, J., Nuño, J., and Cavazos, J. (2014, January) Process improvement in emergency units. two analysis cases. In: IIE Annual Conference. Proceedings ( $p$. 3620). Institute of Industrial Engineers-Publisher.

Mason, S. E., Nicolay, C. R., and Darzi, A. (2015) The use of Lean and Six Sigma methodologies in surgery: A systematic review. The Surgeon, Vol. 13, No. 2, pp. 91-100.

McIntosh, B., Sheppy, B., and Cohen, I. (2014) Illusion or delusion-Lean management in the health sector. International journal of health care quality assurance, Vol. 27, No. 6, pp. 482-492.

Medici, A. C. (2001) Hospitais universitários: passado, presente e futuro. Rev Ass Med Brasil, Vol. 47, No. 2, pp. 149-156.

Miller, R., and Chalapati, N. (2015) Utilizing lean tools to improve value and reduce outpatient wait times in an Indian hospital. Leadership in Health Services, Vol. 28, No. 1, pp. 57-69. 
Molina-Garduza, L. A., and Rivera-Barragán, M. del R. (2012) Percepción del cliente interno y externo sobre la calidad de los servicios en el Hospital General de Cárdenas, Tabasco, 2011. Salud en Tabasco, Vo. 18, No. 2, pp. 56-63.

Pissinati, P. D. S. C., Haddad, M. D. C. L., Rossaneis, M. Â., Gil, R. B., and Belei, R. A. (2014) Costs of reusable and disposable aprons in a public teaching hospital. Revista da Escola de Enfermagem da USP, Vol. 48, No. 5, pp. 915-921.

Pumar-Méndez, M. J., Attree, M., and Wakefield, A. (2014) Methodological aspects in the assessment of safety culture in the hospital setting: A review of the literature. Nurse education today, Vol. 34, No. 2, pp. 162-170.

Razzaque, A., and Karolak, M. M. (2010) A quantifiable transcultural knowledge management model to improve quality of healthcare: a case study of The Kingdom of Bahrain. Journal of Economic Development, Management, IT, Finance, and Marketing, Vol. 2, No. 1, pp. 111-149.

Reznick, D., Niazov, L., Holizna, E., \& Siperstein, A. (2014) Applying industrial process improvement techniques to increase efficiency in a surgical practice. Surgery, Vol. 156, No. 4, pp. 752-759.

Sguario, V. M. G., and Silva, T. E. da (2010) Sistemas de informação no contexto da gestão hospitalar: um estudo no hospital universitário de Londrina. Encontro Nacional de Pesquisa em Ciência da Informação, Vol. 11, No. 1, 25 p.

Simon, R. W., and Canacari, E. G. (2014) Surgical scheduling: a lean approach to process improvement. AORN journal, Vol. 99, No. 1, pp. 147-159.

Skeldon, S. C., Simmons, A., Hersey, K., Finelli, A., Jewett, M. A., Zlotta, A. R., and Fleshner, N. E. (2014) Lean methodology improves efficiency in outpatient academic uro-oncology clinics. Urology, Vol. 83, No. 5, pp. 992-998.

Timmons, S., Coffey, F., and Vezyridis, P. (2014) Implementing lean methods in the Emergency Department: The role of professions and professional status. Journal of health organization and management, Vol. 28, No. 2, pp. 214-228.

Toussaint, J. S., and Berry, L. L. (2013, January) The promise of Lean in health care. In: Mayo Clinic Proceedings (Vol. 88, No. 1, pp. 74-82). Elsevier.

Vermeulen, M. J., et al. (2014) Evaluation of an emergency department lean process improvement program to reduce length of stay. Annals of emergency medicine, Vol. 64, No. 5, pp. 427-438.

Vieira, D. D. S. (2015) Avaliação tecnológica e incorporação de equipamentos médicos nos hospitais de ensino: uma experiência no Hospital Universitário de Brasília-HUB. Masters Dissertation in Economy, 106 p.
Warner, C. J., Walsh, D. B., Horvath, A. J., Walsh, T. R., Herrick, D. P., Prentiss, S. J., and Powell, R. J. (2013) Lean principles optimize on-time vascular surgery operating room starts and decrease resident work hours. Journal of vascular surgery, Vol. 58, No. 5, pp. 1417-1422.

White, M., Wells, J. S., and Butterworth, T. (2014) The impact of a large-scale quality improvement programme on work engagement: Preliminary results from a national crosssectional-survey of the 'Productive Ward'. International journal of nursing studies, Vol. 51, No. 12, pp. 1634-1643.

Witiuk, I. L. (2014) Serviço social hospitalar: o processo de trabalho do assistente social. Intervenção Social, Vol. 28, No. 1, pp. 19-28.

Yin, R.K. (2014) Case Study: design and methods. Fifth edition. Sage Publication.

Zhu, Y., Lu, Z., and Dai, H. (2014) Improving Efficiency and Patient Satisfaction in a Peripherally Inserted Central Catheter Center Using Lean-Based Methodology. Journal of the Association for Vascular Access, Vol. 19, No. 4, pp. 244255. 